\title{
The Development Of Social Emotional On Children From Broken Families
}

\author{
Anizar Ahmad ${ }^{1}$, M.Pd.,Dra. Yuhasriati. M.Pd. ${ }^{2}$, Muliana, S.Pd ${ }^{3}$ \\ $\left\{\right.$ anizar.ahmad@gmail.com $\left.{ }^{1}\right\}$ \\ ${ }^{1.2}$ The teacher of Teacher Training Faculty, Syiah Kuala University. \\ ${ }^{3}$ The Teacher of Kindergarten, Pidie Jaya
}

\begin{abstract}
This study aims to determine the behaviour of children from families whose parents divorced in Ulim sub-district, Pidie Jaya regency. This study used descriptive qualitative method. The data was collected by observation and interview. The subjects in this study amounted to five children aged 5-6 years who come from a divorced family. The result showed that the divorced families had a negative impact on the development of children, one of which is the emotional social development that the children are unable to socialize with the surrounding environment, experiencing pressure, violence, emotions and uncontrolled behaviour. Mostly behaviours shown by the children are, in the form of physical and verbal violence. The physical violence by children are such as throwing and slamming when their desire is not met. Meanwhile the verbal violence committed by children like threatening his friends, speaking harshly, and mocking their friends. Such behaviour can occur due to parents who lack love for their children.
\end{abstract}

Keywords: Emotional social development of children, Family divorced

\section{Introduction}

Family is a social unit relatively small in a society that consists of father, mother, and children. A group of human who live together due to the bond of marriage and blood ties, family consists of father, mother and children who live under the same roof. Family is also a place to share and discuss one another about what they experience. As stated by [1] "Family life contains a function to fulfill and channel the emotional needs of its members, while also providing opportunities for the socialization of its members, especially children".

The whole family is everyone's dream, because a whole family will not make a person lose each other and there is a happiness that cannot be expressed in words. Many things can be done with family. A decent household will produce a whole and peaceful family. In this case, [2] suggested "Households are social groups that are usually cantered on one family, plus several other residents who dwell and live together in one house so that it becomes a unity". Therefore, if father and mother succeed in playing their respective roles well, then there will be created a family that has a whole unit and will give happiness to their children. However, if both parents commit divorce, the family is no longer intact, because there is no more unity in the household and the family will be divided. 
Troubled families are not only giving a bad influence on children's development, even children will experience poor parenting from their parents. They manage to learn bad behavior of their parents just like mother and father who often squabble and beat each other in front of children, children will carry the bad things they often see to their surroundings like to their peers, and those children will be dissident and fond of hostility. Due to problems that cannot be solved, it leads many parents choose to divorce.

Divorce is very much happening between married couples, because they are no longer willing to foster marriage relationships between them with various reasons they propose, many publications about divorce issues adorn social media, such as television and print media. Frequently, divorces between husbands and wives are basically occurred because their own desires, even some people plan their divorce on purpose. Disputes between husband and wife finally lead to divorce. "Divorce is the culmination of poor marital adjustments, and occurs when the husband and wife are no longer able to find ways to solve problems that can satisfy both parties" [3]. Ideally, parents are fully responsible for the development of their children.

Children are supposed to obtain proper love and attention from their parents, because love and affection are able to make children feel comfort and security by having parents who protect them. However, sometimes someone's way of life is not in accordance with what they expected, so many people feel their lives are not satisfied with what they own. This happens because the husband is unable to fulfill whatever the wife demands, as the result there is a conflict between them, as well as from the husband who feels himself lose dignity on wife's viewpoints, then divorce is the way out of them, and many more problems occur between other husbands and wives. Parents have no idea how much divorce affects on their children, only few people are eager to fathom their children's feelings, they don't even think about their own feelings, as if there is no remorse left. This is in accordance with the opinion of E. Mavis Hetherington [4] below:

Describing the period during separation, and also the first two years after the divorce, as a time of serious disruption to parents' relationships with their children. During this period, parents who are too busy or whose emotions are disturbed and a child who is sad and demanding, is more likely to face difficulties to support each other, entertain each other and perhaps even exacerbate their difficulties.

Divorce is a very detrimental event and causes a very deep trauma for children, and makes the children feel so devastated by that divorce, even children will feel the loss of one of their beloved family members. Divorce is very influential on children's personality even in their psychology, many children do not easily accept the decision of their parents, maybe adults are very different from children, some adults can turn to friends if they face a serious problem, or other closest people to share what they undergo. [5] said "The memory of little children is still plain and has not been tainted with various problems. Therefore, they are very easy to memorize even though they are clueless. That is the nature of children, children are not easy to forget an event that they experienced, and it will be recorded in their brain, even children feel uncomfortable for what they experience, children will recall the incident until adulthood, even they may keep revenge on one of their parents."

Divorce makes children lose affection and love of their parents, family becomes divided and life is filled with problems which are difficult for children to think and solve. As stated by Hetherington and Clingempeel [6] "The damage of children's psychological development such as depression, withdrawal from social interaction, very low social competencies and various problems their behavior disorder are closely related to emotional difficulties faced by children of couples who are in the event of a conflict that has eventually led to the divorce process". 
From the background above, the formulation of this research problem is "What is the social emotional development of children from divorced families in Ulim Sub-district, Pidie Jaya Regency?"

Development takes place continuously, every human being will experience development throughout his life. Development will not stop at one point. However, it will happen continuously as long as humans still breathe. Development from an early age will affect development as an adult. This is in line with the opinion of Jamaris [7] suggested "Development is a cumulative process, meaning that previous developments will be the basis for further development. Therefore, if there are obstacles to previous developments, then further developments tend to gain obstacles".

\subsection{Child Social Development}

Children's social development is usually interpreted as the attitude or behavior of children in socializing and adjusting to their peers or others around them. When children are socializing with people around them, the reaction is usually sad, happy, angry, and bored. As stated by [8] "Social development is the acquisition of the ability to behave in accordance with social demands, namely people who are capable of society". Based on the understanding above, it can be concluded that social development is the ability of children to bring themselves up and adapt themselves to the surrounding environment that is, by behaving well towards people around, so that children are able to be accepted by those around them.

\subsection{Development of Children's Emotion}

Emotion is an overflowing feeling for someone to express themselves, The emotions are often shown by someone are closely related to one's behavior. This is in line with [8] "Emotion is a feeling that has a lot of influence on behavior".

Emotional or commonly known as EQ (English: Emotional Quotient) is the ability of someone to receive, assess, manage, and control their emotions and others around them. In this case, it refers to the feeling of information about a relationship. While development refers to the capacity to provide valid reasons for a relationship. A person's emotion can be seen from the attitude or behavior more obviously. This is in accordance with what Darwin put forward [9], namely "emotional expressions can be observed from visible behavior, such as posture, gestures or body movements and facial expressions". [9] also added that "Emotional expression consists of verbal and nonverbal expressions. Verbal expressions are such as writing in words, talking about emotions experienced, and others. Nonverbal expressions are such as changes in facial expressions, vocal expressions or (tone of voice and sequence of pronunciation), physiological changes, body movements and cues, emotional actions".

\subsection{The Impact of Parental Divorce on Child's Social Emotional}

Divorce is the breakup of a family because one or both partners decide to leave each other so they stop doing their obligations as husband and wife. In addition, according to [10] "Divorce of parents is a family condition that is not harmonious, unstable or messy". Therefore, it can be concluded that divorce is the end of a husband and wife relationship because of a mismatch between the two and decided by law. Divorce does not only cause psychological and emotional disturbances for divorced couples but children will be affected as well along with their social emotional. The impact of divorce on children is heavier than that of parents. Sometimes children will feel trapped in the middle when parents divorce. Anger, fear, anxiety about separation, sadness and shame are reactions for most children from the effects of divorce. Divorce that occurs in a family has an impact that affects the children's 
lives and conditions. Children who experience obstacles in their fulfillment related to love and having parents must face the fact that their parents have divorced. Children obtain a bad picture of family life. Divorce almost always causes children are sad, angry, and weak. Children feel alienated among the community which consists mostly of families who are united.

Children who are victims of divorce will feel sad, embarrassed, and insecure because the parents they are proud of our ending up divorced. As an outlet for these feelings, the children release it by:

1) Confining in a room, not hanging out with friends because they feel ashamed, sad, and insecure.

2) Wandering continues as a sign of protest against parents. Hoping this way parents will reconcile, but by doing that way it will actually plunge children into the negative things they demand.

3) Active in activities. The bitter experience of divorcing parents actually triggers the spirit of working, learning, and doing positive activities. Although being active in activities but they still cannot get rid of the shadows of sad, embarrassed, and insecure about parental divorce.

Leslie [11] explained that "Trauma experienced by children due to parental divorce is related to the quality of relationships in the previous family". Children who are traumatized by their parents' divorce will be very disturbed at everything they will do, since the separation made by parents causes the children become quiet and even become dissident and unruly. In this case, [12] said "Divorce is a suffering, a traumatic experience for children. Children obtain a lot of pressure, in the sense of a less harmonious home atmosphere, loss of father. And also the environment that requires him to make adjustments and changes in the adjustments. Because when their parents' divorce, the children will experience pressure and environmental conditions that require them to make environmental adjustments as a result of the divorce of their parents. Therefore, children may be underestimated by their friends or other people around them, they will automatically experience discrimination, while they are still at preschool stage, they will despise to be ridiculed or ostracized by those around them". [13] explained that "Children who are victims of divorce will experience a personality crisis, so their behavior is often wrong. They experience emotional and even neurotic disorders. Cases of broken home families are often found in schools, such as children being lazy to learn, being alone, being aggressive, truant, and like to oppose teachers".

The effect of divorce does not only affect early childhood, but also affects teenagers. Even early children have experienced difficult and hateful things which will be carried the bad traits into adulthood, as stated in Trommsdoff's research [14]. "Teenagers who get lack of supports from their parents will likely grow up as pessimistic individuals, lack expectations about the future, lack of trust in their abilities, and their thinking becomes less systematic and less directed". The same as the opinion above according to Joseph (2009: 202) "Children whose family relationships are full of conflict, tension and disputes, and parents give less love, then adolescents will experience failure to reach their identity properly, experience confusion, conflict or frustrating". The influence caused by divorce is enormous, and as the result, the children's future is not guaranteed to suit the expectations of all parents.

The factor of parental divorce greatly affects the development of children, because psychologically the children have a grim period in family problems, and a lack of parental love, leads to the emotional impact on children. In this case, Krantzer [15] explained that "Divorce is the end of the relationship between two people who have lived together as husband and wife, this has affected the children as well”. 


\section{Research Method}

The type of research employed in this study is a descriptive research with a qualitative approach. The use of this study aims to obtain data as accurate as possible concerning the development of children's behavior from divorced families in Ulim Sub-district, Pidie Jaya Regency. "Descriptive is a method of examining the status of a group of people, an object, a condition, a system of thought, or a class of events in the present. The purpose of this descriptive research is to conduct description or painting of the facts, traits and relationships between the phenomena being investigated systematically, factually and accurately,’[16]. The research subjects in this study were children who came from an incomplete family or children who were victims of divorce. The subjects chosen by the researchers amounted to 5 children aged 5-6 years old who came from 3 villages, namely 3 children were from Grong-grong Capa village, 1 child from Tanjong Ulim village and the other 1 was from Pulo Ulim village, all the three villages are in Ulim Sub-district, Pidie Jaya Regency. The object in this study is the development of children's behavior from divorced families in Ulim Sub-district, Pidie Jaya Regency. Data collection was done by observing children from divorced families and interviews with parents of the children.

\section{Result And Discussion}

Based on the results of observations and interviews that researchers did with informants in the field, researchers found various information and events related to the problem of how the children's behavior develops from divorced families. The information that the researchers obtained is actual information which the researchers obtained directly through interviews with several respondents who were close to the subject of the study. As researchers have found in the field that subjects I, II, III, IV, and V are not still emotionally stable, their social aspects still need to be improved and their behavior is still unstable. Based on the research that researchers have committed, there have been found the types and forms of behavior that are often carried out by children who are the subjects in the study of Pidie Jaya District, Ulim Sub-district, namely slamming, throwing, and mocking. It becomes a problem for the lives of children and others.

\subsection{Family Environment}

Family is the first school for children so that everything is well-provided for the children to take in the family, which is how children will implement it to the outside world. All children's development depends on their parents, including their social emotional aspects which includes all their behavior. This is in accordance with that described by [1] "Family life contains a function to fulfill and channel the emotional needs of its members, while also providing opportunities for socializing its members, especially children". Based on the results of research that researchers have conducted, children's behavior in their daily lives was still poor, the subjects had not been able to self-regulate, emotional expression and excessive behavior, uncontrolled and more aggressive, frustrated, shy and unable to accept the situation because the subjects did not have good habit in their environment, they were faced with divorced problems of their parents who unwittingly influence their behavior. Children ought to get love from their families, gain proper treatment, because the love and affection of both parents is 
very necessary for their development. If children do not get what they require, they will feel the negative impact. This is in accordance with what was stated by [17] "Children who are left by divorced parents also feel a negative impact. They are confused about who to join. They cannot process identification with parents. As a result, there are no positive examples that must be replicated. Indirectly, they have negative (bad) viewpoints on marriage. However, the parents' divorce will bring traumatic feelings for children surely." Parents are the ones who determine the good and bad behavior of their children.

\subsection{Development of Children' Emotions}

Children whose the need of their emotions are not fulfilled will not be stable, especially the condition of those from divorced families. Incomplete families cause problems on the children, they will feel depressed by the condition of the inharmonious home. This is in accordance with [10] "Divorce of parents is a family condition which is inharmonious, unstable or messy". Such conditions cause children's emotions unstable. The children will vent their anger to anyone. As commonly occur with subject at the time of anger, the subject vent to other people's friends. A person's emotions are described in the form of behavior as stated by [8] "Emotion is a feeling that has a lot of influence on behavior". Starting from emotion, it becomes a form of behavior which is often or becomes a habit committed by everyone, both good and bad behavior.

\subsection{Social Behavior of Children}

Social behavior is truly essential because as a social being, we must be able to socialize with people around us. Children who have problems in their families will usually remember what they saw, even though they attempt to forget. However, it will not make the children forget everything. Instead, it will be continuously memorized and stored in the memory of their brain until they are adults. Just like Judith Wallerstein in her book Second Chances: Men, Women and Children a Decade After Divorce [18] stated that:

"Children, who are victims of divorce, even though they can live happily in their adult years, bad experience (their parents' divorce) will be remembered throughout their lives.

Children as silence victims, even though they grow up as happy adults and manage to adjust well, tend to have behavioral problems in their childhood and adolescence, compared to children from whole families.

Parental divorce makes children lose the love and affection of their parents. Causing children feel embarrassed, angry, rude, and dissident. Whereas the children at this age are able to control emotions, understand others, possess responsibility, play with peers, and cooperate with others. As stated by [10] "Children whose family relationships are full of conflict, tension and disputes, and parents who give lack of love, then adolescents will experience failure to reach their identity properly, will experience confusion, conflict or frustration". This happens without them (parents) knowing that what is done is incorrect, harming themselves and others. Problems occur in their home will be an example for children. It is obvious that divorce is very detrimental to children's development. The role of parents is completely crucial in children's lives, because parents are the first people seen by the children. Children mostly spend time at home. Both good and bad care gained by children will give an impact on them.

Based on the research that has been conducted, divorce of parents is able to have an adverse effect on children. Because troubled families give a negative impact on children. Until at the moment the children notice the damage that occurs in the family environment puts pressure on them, they will recall about a bad event in their family until they grow as adults. As the result, it bothers their social emotional depicted in the form of unfavorable behaviors, such as emotions and behavior which cannot be controlled by children, unable to socialize 
with the surroundings, even shut themselves from the surrounding environment and become a shy person. It is clear that this is truly disturbing for the development of children in the future.

\section{Conclusion}

Based on the results of research data analysis, it can be concluded that children who come from divorced families in Ulim Sub-district, Pidie Jaya Regency, the development of their behavior tends to be deficient due to lack of love from their parents. Poor behavior can be seen from the expression shown by the children, namely excessive emotions and behavior, uncontrolled and selfish emotions, frustration that haunts their soul, and is shy and unable to accept their situation. In addition, it is clear about the behavior shown by children, namely physical and verbal violence. Verbal violence committed by children is like threatening their friends, saying harshly, and mocking their friends. Then physical violence done by children is like throwing and slamming. This behavior can occur due to parents who give inadequate love to their own children.

\section{Suggestion}

Based on the conclusions of the study results in Ulim Sub-district, Pidie Jaya District, several suggestions can be recommended are:

1. Parental communication is an important thing that must be recognized by parents, with the existence of good communication between mother and children, it is unlikely that the children will have social emotional problems because there is always assistance from parents, even though parents are no longer together.

2. Parents should be completely responsible for their children. After giving birth, raise them and pay attention to their development. Parents must also act as friends for children by involving themselves into their world and understand them.

3. Explanation from parents about the condition of their family, everything must be conveyed to the children a little by little, so that the children manage to accept the condition of their family.

\section{References}

[1] Soelaeman, Pendidikan dalam Keluarga (Education in the Family). Bandung: CV Alfabeta, 1994.

[2] Manurung and H. Manurung, Manajemen Keluarga (Family Management). Bandung: Indonesia Publising House, 1995.

[3] E. B. Hurlock, Psikologi Perkembangan (Psychology of Development). Jakarta: Erlangga, 1993.

[4] D. Goleman, Working With Emotional Intelligence: Kecerdasan Emosi untuk Mencapai Puncak Prestasi / Emotional Intelligence to Achieve the Peak of Achievement). Jakarta: Pt Gramedia Utama, 2003.

[5] S. M. S. Mursi, Seni Mendidik Anak (The Art of Educating Children). Jakarta: Pustaka AlKautsar, 2003

[6] S. S. Sadarjoen, Hubungan Orang Tua-Remaja (Parents-Youths Relation). Jakarta: Kompas, 2005.

[7] Y. N. Sujiono and B. Sujiono, Bermain Kreatif Berbasis Kecerdasan Jamak (Playing Creatively Based on Multiple Intelligences. Jakarta: Indeks, 2010. 
[8] Soefandi, Indra, and A. Pramudya, Strategi Mengembangkan Potensi Kecerdasan Anak (Strategy to Develop Children's Intelligence Potential). Jakarta: Bee Media Indonesia, 2009.

[9] R. Mashar, Emosi Anak Usia Dini dan Strategi Pengembangannya (Early Childhood Emotions and Development Strategies). Jakarta: Kencana Prenada Media Group, 2011.

[10] S. Yusuf, Psikologi Perkembangan Anak dan Remaja (Child and Youth Development Psychology). Bandung: Remaja Rosda Karya, 2009.

[11] T. O. Ihromi, Bunga Rampai Sosiologi Keluarga (Potpourri of Family Sociology). Jakarta: Yayasan Obor Indonesia, 2004.

[12] S. D. Gunarsa, Psikologi untuk Keluarga.(Psychology for Family). Jakarta: Gunung Mulia, 2002.

[13] S. S. Willis, Konseling Keluarga (Family Counseling). Bandung: Alfabeta, 2011.

[14] Desmita, Psikologi Perkembangan (Psychology of Development). Bandung: Remaja Rosdakarya, 2009.

[15] R. S. Endah, Statistik 1 (Pengumpulan, Pengolahan, dan Pengujian / Collecting, Processing and Testing ). Jakarta: Fakultas Psikologi Universitas Indonusa Esa Unggul, 2005.

[16] Nazir, Metode Penelitian (Research Method). Jakarta: PT Ghalia Indonesia, 2009.

[17] A. Dariyo, Psikologi Perkembangan Dewasa Muda (Development Psychology of Young Adults). Jakarta: Grasindo, 2008.

[18] I. Musbikin, Mengatasi Anak-anak Bermasalah (Overcoming Troubled Children). Yogyakarta: Mitra Pustaka, 2008. 
